\title{
Immunosuppression in progeny of chinook salmon infected with Renibacterium salmoninarum: re-analysis of a brood stock segregation experiment
}

\author{
Owen S. Hamel* \\ Northwest Fisheries Science Center, National Marine Fisheries Service, 2725 Montlake Boulevard East, Seattle, \\ Washington 98112, USA
}

\begin{abstract}
Female spawner infection level and temperature variation through rearing are sufficient to explain in-hatchery mortality rates and infection levels and smolt to adult return ratios (SARs) of progeny of Renibacterium salmoninarum infected spring chinook salmon. Data from published reports and manuscripts regarding a 1988 brood stock segregation experiment that held progeny of highly infected female spring chinook salmon spawners separate from progeny of other spawners during 16 mo of hatchery rearing are analyzed to test the hypothesis that immunosuppression could account for differences in survival and infection levels between the 2 segregates. Immunosuppression, caused by the presence of the p57 antigen of $R$. salmoninarum in sufficient concentration within the salmon egg before spawning, can account for differences in infection levels, mortality rates, and SARs for each hatchery raceway in that study. This immunosuppression may be characterized by immunotolerance, or might only affect cell mediated immunity, which appears the most effective defense mechanism against $R$. salmoninarum infection, as antibody production can result in tissue damaging antibody-antigen complexes. Low-temperature mediated immunosuppression can account for the nearly identical trajectories of infection and mortality between the 2 segregates during the first $8 \mathrm{mo}$ of hatchery rearing. There is no evidence of widespread vertical infection from spawner to progeny, nor is there evidence that brood stock segregation reduces overall mortality. Rather, the suppression of cell-mediated immune mechanisms may condemn progeny of highly infected female spawners to an almost certain eventual premature demise.
\end{abstract}

KEY WORDS: Immunosuppression · Renibacterium salmoninarum • Bacterial kidney disease · p57 · Cell mediated immunity $\cdot$ Temperature $\cdot$ Immunotolerance

\section{INTRODUCTION}

Bacterial kidney disease (BKD) is a chronic, systemic disease which causes mortality throughout the salmonid life-cycle. BKD has been of particular concern for spring chinook salmon Oncorhynchus tshawytscha from the Snake River Basin (e.g. Bullock \& Wolf 1986, Raymond 1988). This concern is highlighted by the prevalence of detectable infection with Renibacterium salmoninarum, the causative agent of $\mathrm{BKD}$; this ranged from 86 to $100 \%$ in collection facilities at Lower Granite, Little Goose and McNary dams between 1988 and 1991 (Elliott et al. 1997). Preva- lences were moderate to high in at least half of Snake River and mid-Columbia River hatcheries tested in each year from 1988 to 1996, with each hatchery recording over $90 \%$ prevalence in at least one year (Maule et al. 1996, VanderKooi \& Maule 1999).

While BKD can occur in epizootics, it is generally a chronic disease and is enzootic in Snake River spring chinook salmon populations. Almost all fish in these populations are infected with Renibacterium salmoninarum at some point in their lifecycle (Elliott et al. 1997) or throughout it, including periods of ocean residence (Banner et al. 1986). Low-level infections may persist for long periods with no apparent adverse 
effects, followed by an eruption of the disease during or after stressful events. Salmon with low levels of the bacteria in their system may act as carriers of the disease. The stresses and endocrinological changes associated with smoltification can result in outbreaks of BKD (Mesa et al. 1999), and high BKD-related mortality rates are associated with ocean entry (Banner et al. 1983). Thus, the primary question is not whether a salmon is infected with $R$. salmoninarum, but what factors affect the course and outcome of the infection given the genotype, condition, and immune functioning of a salmon, and the life stages, environmental conditions and stressors experienced by the salmon while infected.

Infected spawners act as conduits, transporting the bacteria back upstream, while the stress and changing physiological demands of returning and preparing to spawn can allow the bacteria to multiply within individual spawners. This is especially of concern for spring chinook salmon which return early in the year and may spend months upstream before spawning. Horizontal transmission on the holding and spawning grounds is suspected to occur, as well as transmission to juvenile salmon in the area. In addition, Renibacterium salmoninarum is passed vertically from female spawners to their progeny (Elliott et al. 1989). $R$. salmoninarum is present in ovarian fluid (Evelyn et al. 1986, Elliott \& Barila 1987, Lee \& Evelyn 1989), which may be an important route of vertical transmission, continuing the cycle of infection. Brown et al. (1996) suggested that significant quantities of the p57 antigen of $R$. salmoninarum may be present in eggs of highly infected females, resulting in immunosuppression in the resulting progeny. Selective culling of infected brood stock over several years greatly reduced infection in 2 Atlantic salmon Salmo salar sea ranches in Iceland (Guđmundsdóttir et al. 2000).

A brood stock segregation study was undertaken beginning in 1988 at the Dworshak National Fish Hatchery (U.S. Fish and Wildlife Service) to observe differences in infection levels and mortality between the 2 segregates (Pascho et al. 1991). Differences in vertical transmission and subsequent horizontal transmission within the separate rearing areas were expected to result in higher infection prevalences and mortality among the progeny of the highly infected brood stock (the 'high-BKD' segregate). While there was higher overall mortality among the high-BKD segregate during hatchery rearing, during in-stream migration to McNary Dam (Pascho et al. 1993) and under saltwater challenge after smoltification (Elliott et al. 1995), as well as reduced overall returns (Elliott \& Pascho 1995), it is by no means clear that vertical transmission alone was responsible for these differences. There was no significant difference in infection level or mortality through the first 8 mo of hatchery rearing when, at the parr stage, both segregates showed relatively high prevalence and levels of infection. After this point, however, much greater mortality was seen among the high-BKD segregate, while reduced infection was observed in both segregates. At smoltification, 16 mo post hatch and just before release, the high-BKD segregate had much higher prevalences and levels of infection than the low-BKD segregate.

BKD is a complex disease with unusual responses to temperature and distinct interactions with the salmonid immune system. The ability of the bacterium to survive entry into phagocytic cells, the effects of temperature and stress on immune system functioning, and the qualities of a particular antigen (p57) of Renibacterium salmoninarum all appear to contribute to the persistence and virulence of the causative bacterium.

Renibacterium salmoninarum has a uniquely powerful ability to induce uptake by tissue cells including the lining of the gastro-intestinal tract (Bruno 1986, Evelyn 1996). Thus, infection is likely when the bacteria are present at sufficient levels in the surrounding water or in cohabiting fish. Ingestion of contaminated faeces during feeding is likely a major route of horizontal infection in seawater net pens (Balfry et al. 1996) and perhaps in hatcheries. Waterborne bacteria infect salmon through the gills, eyes, ingestion, or lesions or abrasions (Evenden et al. 1993). Mitchum \& Sherman (1981) confirmed that horizontal transmission occurs in natural systems. $R$. salmoninarum can survive for up to $4 \mathrm{~d}$ in river water, 4 to $5 \mathrm{wk}$ in sterile freshwater, $3 \mathrm{wk}$ in fecal matter (Austin \& Rayment 1985) and 2 wk in sterile seawater (Balfry et al. 1996). Therefore, being in close quarters with other infected fish is not a prerequisite for infection. In riverine systems, bacteria from upstream may be important in transferring the disease between stocks and between species.

Temperature affects fish health, immune system functioning and bacterial growth. BKD-related mortality in coho salmon Oncorhynchus kisutch (mean weight $7 \mathrm{~g}$ ) artificially infected with $3 \times 10^{8}$ bacteria was highest for temperatures in the range of 6.7 to $12.2^{\circ} \mathrm{C}$, with decreasing mortality between 12.2 and $20.5^{\circ} \mathrm{C}$, while mean time to death decreased with increasing temperature (Sanders et al. 1978). Results were similar for juvenile steelhead trout O. mykiss $(18 \mathrm{~g})$ but were confounded by a high incidence of BKD-independent mortality among both infected and control groups. Juvenile sockeye salmon O. nerka (38g) showed less protective effect of high temperatures, experiencing $100 \%$ mortality at all temperatures except $20.5^{\circ} \mathrm{C}$ (and $3.9^{\circ} \mathrm{C}$, for which the experiment was too short to see complete mortality). At $20.5^{\circ} \mathrm{C}, 3$ of $49(6 \%)$ survived, despite the fact that the mean time to 
death for those that died was $26 \mathrm{~d}$ in a $90 \mathrm{~d}$ experiment, demonstrating a positive effect of at least this highest temperature on sockeye salmon survivorship vis-à-vis Renibacterium salmoninarum infection (Randomization test; $\mathrm{p}<0.005)$. The differences in survivorship observed between the sockeye and coho salmon could as easily be due to differences in average size and developmental stage of the 2 species at the beginning of the experiment as to differences between the species in general, as temperature is only one of a multitude of factors affecting the relationship between infection level and the probability of survivorship. Nearly identical experiments were performed with other bacterial diseases of fish, caused by Flexibacter columnaris, Aeromonas salmonicida and A. hydrophila (Holt et al. 1975, Groberg et al. 1978). BKD was the only one of these diseases for which higher temperatures $\left(17.8\right.$ and $\left.20.5^{\circ} \mathrm{C}\right)$ resulted in decreased total mortality. BKD also produced the highest mortality rates at low temperatures $\left(3.9\right.$ and $6.7^{\circ} \mathrm{C}$ ). All this suggests a monotonic increase in the salmonid immune system effectiveness against $R$. salmoninarum with temperature, such that at low infection levels, and in the absence of other stressors or cofactors, recovery is likely at relatively low temperatures, whereas with higher infection levels and/or other stressors, recovery may be unlikely even at the highest physiologically tolerable temperatures.

Very high temperatures or rapid changes in temperature are stressful to salmonids, but these very high temperatures also cause a more rapid breakdown of the p57 antigen (Griffiths \& Lynch 1991), perhaps reducing the virulence of the disease. Renibacterium salmoninarum reproduces most quickly at 15 to $18^{\circ} \mathrm{C}$ (Weins \& Kaattari 1999). This partially accounts for the reduced time to mortality at higher temperatures.

Low temperatures adversely affect the functioning of the cell mediated immune system in teleosts (Bly \& Clem 1992, Hardie et al. 1994). Immune systems of fish have adapted to be optimally competent near normal summer temperatures for each species, while temperatures significantly below that optimum may be immunosuppressive (Manning \& Nakanishi 1996). In teleosts, low temperatures impair the proliferation and action of cells that appear to be analogous to mammalian helper T-cells, reducing the production of cytokines, specifically the macrophage activating factor (MAF), and eliminating an important route of stimulation of phagocytes, which Hardie et al. (1994) demonstrated in rainbow trout Oncorhynchus mykiss. This is especially true when the T-cells first encounter an antigen at low temperatures (Manning \& Nakanishi 1996). Primed T-cells (previously exposed to the antigen at non-immunosuppressive temperatures) appear to be more resilient to the effects of low tem- peratures and are affected to a lesser degree (Bly \& Clem 1992).

Renibacterium salmoninarum can survive entry into and reproduce within phagocytic cells, thus avoiding the humoral immune system (Gutenberger et al. 1997). MAF stimulates phagocytic cells to inhibit the growth of $R$. salmoninarum (Hardie et al. 1996). Any suppression of an immunological pathway that stimulates phagocytic cells to destroy or inhibit the bacteria within may greatly affect the ability of the salmonid immune system to fight off $R$. salmoninarum infection. Low temperature is one cause of such suppression of the cell mediated immune response. A second cause is demonstrated by Jansson et al. (2003), who found a reduced T-cell mitogen response in rainbow trout 4 to 6 wk after challenge with $R$. salmoninarum, indicating a suppressive effect of the bacterium or its antigens on the cell mediated immune response.

The p57 antigen is the major soluble antigen of Renibacterium salmoninarum (Weins \& Kaattari 1999) and may be present in high densities in tissues and fluids of infected salmon (Evenden et al. 1993). Soluble antigen concentration (i.e. the concentration of the soluble antigenic fraction which includes p57 and its breakdown products as well as other soluble antigens) is an important virulence factor as p57 has immunosuppressive and tissue destructive properties. The p57 antigen is known to agglutinate salmon leukocytes (Weins et al. 1999) and to suppress antibody production against unrelated antigens in vitro (Turaga et al. 1987). The p57 antigen is a potent inhibitor of the phagocyte respiratory burst response at high concentrations and diminishes the bactericidal activity of juvenile chinook salmon macrophages against Aeromonas salmonicida, an unrelated pathogen (Siegel \& Congleton 1997). $R$. salmoninarum produces large amounts of the p57 antigen (Weins \& Kaattari 1999), both in serum and while in intracellular residence, and these antigens can neutralize the vast majority of any existing anti-p57 antibodies. The resulting antibody-p57 complexes remain in tissue and contribute to tissue destructive hypersensitivity resulting in granulomas (Bruno 1986) and glomerulonephritis (Sami et al. 1992). Thus, the specific, antibody-mediated immune response can be considered a pathological immune response and an important factor in BKD-related mortality (Kaattari \& Piganelli 1997).

Vertical infection may be important in the transmission of the disease between generations. Evelyn et al. (1984) found the in-ovum infection rate to be $14 \%$ in eggs from a single very highly infected female coho salmon spawner $\left(4 \times 10^{9}\right.$ cells $\mathrm{ml}^{-1}$ in ovarian fluid). Other studies found even lower levels of vertical transmission (1 to 6\%) (Evelyn et al. 1986, Lee \& Evelyn 1989). While a more recent study has suggested that 
these numbers might underestimate actual vertical infection rates due to incomplete detection (Brown et al. 1994), vertical transmission alone, without evidence of increased horizontal transmission, immunosuppression, or both, is unlikely to account for large increases in infection or decreases in survivorship of progeny of infected females, especially if the majority of these spawners have only low to moderate infection levels, as was the case in the 1988 Dworshak brood stock segregation study.

It may be that the p57 antigen in soluble form is taken up by eggs from the surrounding ovarian fluid or introduced directly from the bloodstream during oogenesis. Alternatively, vertical infection and subsequent antigen secretion could result in high antigen concentrations within the egg. These antigen concentrations, regardless of source, may cause progeny to be immunosuppressed vis-à-vis the p57 antigen and much less capable of resisting Renibacterium salmoninarum infections. Progeny resulting from eggs injected with $100 \mathrm{ng}$ of the p57 antigen had much reduced immune response to the bacterium and increased BKD-related mortality, even when challenge with $R$. salmoninarum was preceded by vaccination (Brown et al. 1996). Injection with only $1 \mathrm{ng}$ of the p57 antigen resulted in no observed effects. Brown et al. (1996) concluded that the presence of the antigen in sufficient quantities within the egg resulted in an immunosuppressive effect, with the 'most likely interpretation of the results' being 'that the immuosuppressive effect of p57 is due to the induction of immunotolerance'. The modeling conducted in this paper does not necessarily imply immunotolerance, requiring only a significantly reduced cell mediated immune response to the pathogen and the p57 antigen, which results in a decreased stimulation of phagocytic cells and/or other killer cells to destroy the bacteria. Whether this is due to T-cell tolerance of the antigen or some other immunosuppressive effect upon cell mediated immunity is immaterial to the results of this analysis. The hypothesis underlying this analysis is that suppression of the cell mediated immune system, likely resulting in reduced stimulation of phagocytosis of $R$. salmoninarum, is the underlying cause of increased morbidity and mortality in juvenile salmon experiencing immunosuppression due either to pre-fertilization exposure to the p57 antigen, post-hatch exposure to low temperatures, or to a combination of these factors. Continued functioning of the antibody mediated response to the infection may actually hasten mortality due to a hypersensitive specific immune response.

Pascho et al. (1991) concluded that 'segregation of brood stock by the ELISA and the MF-FAT can be used to reduce the prevalence and levels of Renibacterium salmoninarium infection in hatchery-reared spring chi- nook salmon...' However, reanalysis using a modeling approach shows the data to be more consistent with the hypothesis that segregation only separates progeny with different susceptibilities to the disease without necessarily changing total disease-induced mortality. Data from the1991 paper and subsequent papers and reports concerning the same segregation experiment (Pascho et al. 1993, Elliott et al. 1995, Elliott \& Pascho 1995) are reviewed here. This analysis supports the hypothesis that immunosuppression induction is responsible for the increased severity of infection with Renibacterium salmoninarum, increased mortality and decreased overall returns from the high-BKD segregate. This, coupled with the effect of temperature on the immune systems of juvenile salmon, is shown to be a likely explanation for the pattern of infection and mortality among both the low and high-BKD segregates throughout hatchery rearing.

\section{MATERIALS AND METHODS}

Data. Data were obtained from one paper (Pascho et al. 1991) and one report (Elliott \& Pascho 1995) detailing the results of the 1988 Dworshak NFH brood stock segregation experiment. The original data concerning in-hatchery infection levels and mortalities were obtained from the investigators. Results from 2 additional papers (Pascho et al. 1993, Elliott et al. 1995) are cited in the 'Discussion'.

The 1988 Dworshak brood stock segregation experiment involved the progeny of 60 female spawners, 30 chosen for the high-BKD segregate due to moderate to high levels of infection, and 30 for the low-BKD segregate, chosen because of little or no evidence of infection. Progeny of 10 spawners were placed in 2 nursery tanks and then transferred to a single raceway, such that raceways B16 to 18 each contained the progeny of 10 of the low-BKD segregate spawners and raceways B19 to 21 each contained the progeny of 10 of the high-BKD segregate spawners. Juvenile salmon from each raceway (or nursery tank) were tested for infection periodically throughout hatchery rearing, and monthly mortalities were recorded. The number of individuals released from each raceway was noted, and all smolts were injected with coded wire tags so that returning salmon could be identified as to their source raceway.

Spawner infection levels. Ovarian fluid antigen levels were detected by Pascho et al. (1991) via the enzyme-linked immunosorbent assay (ELISA) and the membrane filtration fluorescent antibody technique (MF-FAT). There was a high degree of correlation between the infection levels observed with these 2 tests when infection was detectible by ELISA $\left(R^{2}=0.89\right.$ 
for ELISA value vs $\log _{10}$ FAT count for FAT count $>10^{4}$, $\mathrm{n}=17$ ). The ovarian fluid ELISA values $E$ were transformed to soluble antigen concentrations $A\left(\mu \mathrm{g} \mathrm{ml}^{-1}\right)$ using the relationship established for this brood stock segregation study by Hamel \& Anderson (2002):

$$
A=10^{\frac{E-0.379}{0.296}}
$$

The ELISA detection limit value was $E=0.050$ which is equivalent to $A=0.077 \mu \mathrm{g}$ antigen $\mathrm{ml}^{-1}$.

Immunosupression induction calculations. The modeling in this paper is based upon the assumption that the p57 antigen is present in the eggs of highly infected female salmon before spawning. Whether this occurs during oogenesis from the bloodstream, afterwards due to uptake from surrounding ovarian fluid, or due to secretion of the p57 antigen from Renibacterium salmoninarum cells within the eggs due to vertical transmission is not assumed to be known. Based upon these possibilities, 2 methods of calculating the number of female spawners in each raceway that produced immunosuppressed offspring were undertaken. In each case, for simplicity, all offspring of these spawners were assumed to experience immunosuppression vis-à-vis BKD.

Method 1: Brown et al. (1996) found that $100 \mathrm{ng}$ of the p57 antigen was adequate to cause immunosuppression in progeny. They also tested a dose of only 1 ng, which had no observed effects. The ELISA test detects soluble antigen fraction, of which the p57 antigen is the major component. In this first method, an average chinook egg size of $0.2 \mathrm{ml}$ and identical volumetric concentrations of antigen in ovarian fluid and eggs were assumed. While the p57 concentration in the salmonid egg may actually be either greater than or less than that of the surrounding ovarian fluid, equivalence was invoked in order to calculate the level necessary for immunosumpression induction in this method, while recognizing the uncertainties both in the relationship between the concentration within and outside of the egg and in the concentration that is necessary in vivo to induce immunosuppression. The assumption was that $250 \mathrm{ng} \mathrm{ml}^{-1}$ ovarian fluid soluble antigen is the cut-off for inducing immunosuppression. This would be equivalent to $50 \mathrm{ng}$ per egg given identical concentrations in the ovarian fluid and the egg. The p57 antigen is the major component of the soluble antigen that is detected, and this is within the same order of magnitude as the $100 \mathrm{ng}$ p57 antigen tested by Brown et al. (1996).

Method 2: The MF-FAT measures the number of bacteria per $\mathrm{ml}$ of ovarian fluid. These numbers range from 0 to 13 billion among the 30 high-BKD spawners. Since the infection levels and effects appear to occur on a logarithmic scale, 5 different points of separation representing 5 different orders of magnitude were chosen to define the threshold level for females to produce immunosuppressed offspring. These were set at $10^{8}, 10^{7}, 10^{6}, 10^{5}$, and $10^{4}$ bacteria $\mathrm{ml}^{-1}$. These could be interpreted as thresholds for vertical infection, with immunosuppression occurring due to inovum antigen secretion by the bacteria (or through other unknown mechanisms), although convincing evidence for a reasonably high degree of vertical transmission exists only for a spawner with greater than $10^{9}$ bacteria $\mathrm{ml}^{-1}$.

In-hatchery infection levels: Pascho et al. (1991) tested juveniles from both segregates for infection via ELISA at 1, 5, 8, 12 and 16 mo after hatch. They pooled tissues from fry (1 and $5 \mathrm{mo})$, parr $(8 \mathrm{mo})$ and presmolts (12 mo) in groups of 5 (fry) or 3 (parr and presmolts) to get adequate material for testing. Smolts (16 mo) were large enough to test tissues from individual fish. Individuals or pools were designated by Pascho et al. (1991) as testing negative or having low, medium or high level infections according to the ELISA results.

As an extension of the afore-mentioned work, the data on infection prevalence and levels from pooled samples were transformed to prevalence and levels for the population by making the assumption that the level seen in the pool reflected the level seen in the highest individual in that pool. As ELISA values reflect a logarithmic transformation from antigen concentrations, this assumption does not overly affect the results, though it does somewhat reduce the estimated proportion of infected individuals from the pooled samples. While the presence of antigen is not always an indicator of infection in an individual, it does reflect either recent infection levels in that individual or the infection prevalence in the environment. Therefore, the estimates of infection prevalences and levels in each of the segregates reflect recent or current infection for each segregate as a whole and are a basis of comparison.

With the above assumption, and given the probability, $p$, of an individual having an infection level above the threshold for positive, medium or high status, and given $m$, the number of fish per pool, then:

$$
\phi=1-(1-p)^{m}
$$

is the probability of a pool being above the threshold in question.

For each level of infection starting with 'high', let $x$ be the number of pools with that level of infection or higher and $n$ be the total number of pools. Then the probability $P$ of seeing $x$ in that level given $p$ is:

where

$$
P(x \mid n, m)=\left(\begin{array}{l}
n \\
x
\end{array}\right) \phi^{x}(1-\phi)^{n-x}
$$




$$
\left(\begin{array}{l}
n \\
x
\end{array}\right)=\frac{n !}{x !(n-x) !}
$$

The maximum likelihood estimator for $\phi$ is:

$$
\hat{\phi}=\frac{x}{n}
$$

and since $p$ can be calculated from Eq. (2) as:

$$
p=1-(1-\phi)^{1 / m}
$$

the maximum likelihood estimator of $p$ is:

$$
\hat{p}=1-\left(\frac{n-x}{n}\right)^{1 / m}
$$

In this way absolute estimates of the proportion of individual fish in each infection stratum for each hatchery stage were obtained. Similarly, the $95 \%$ binomial confidence intervals for $\phi$ were converted to $95 \%$ confidence intervals for p using Eq. (6).

In-hatchery mortality. In-hatchery monthly mortality rates were re-calculated for each raceway from the original data, taking into account those fish removed for testing at 1, 5, 8, 12 and 16 mo post hatch, by calculating the marginal survival rate for each month for those individuals which were not removed in that month.

The mortality observed in the raceways before release was modeled by assuming that $35 \%$ of the immunosuppressed progeny and $10 \%$ of the others died before release. This accounts for the approximate $10 \%$ and $19 \%$ in hatchery mortalities among the low and high-BKD segregates reported in Pascho et al. (1991). In particular, assuming that the $10 \%$ low-BKD mortality rate applies to the progeny of 19 high-BKD female spawners assumed to have inadequate infection levels to induce immunosuppression, the mortality rate $\mu$ among progeny of 11 high-BKD female spawners which were assumed to produce immunosuppressed progeny can be found by:

$$
\frac{19}{30}(0.10)+\frac{11}{30}(\mu)=0.19
$$

thus:

$$
\mu=\frac{30}{11}(0.19)-\frac{19}{11}(0.10)=0.34 \overline{45} \cong 35 \%
$$

One of the 3 low-BKD raceways (Raceway B18) received juvenile salmon from a nursery tank that experienced very high and unexplained morality during the first 2 mo post hatch. The average mortality in the 2 low-BKD raceways without an anomalous early mortality event was $8.2 \%$, and mortality data from the 3 highBKD raceways did not include any anomalous early mortalities. Thus, using a non-immunosuppressed inhatchery mortality rate of $8.2 \%$ was considered. The average value of $10 \%$ was retained for simplicity and because the higher BKD-related mortality rate among the high-BKD segregate may well have led to increased bacterial concentrations in the water and slightly in- creased mortality among the non-immunosuppressed fish. Assuming 8.2 and $37.5 \%$ mortality rates was found to produce nearly identical results.

Comparison of hypotheses to explain differences in smolt to adult returns. Adult returns from the 3 lowBKD raceways were compared to adult returns from the 3 high-BKD raceways. The mean rate of return $\rho$ from the 3 low-BKD raceways was taken to be the true probability of return for each individual fish released. A Poisson distribution was assumed, with mean $\rho \mathrm{N}$, where $\mathrm{N}$ is the number released from each raceway or for each segregate as a whole. To detect lower returns from the high-BKD segregate, a 1-sided test (with $\alpha=$ 0.05) was used for observed returns against a null hypothesis that the probability of return for individuals in each raceway or segregate was greater than or equal to $\rho \mathrm{N}$.

In order to determine if immunosuppression alone could explain the difference in adult returns between the 2 segregates, the proportional returns from each raceway were re-calculated to represent the proportion of non-immunosuppressed progeny returning, with the assumption that the probability of return for immunosuppressed fish was negligible. This required first estimating the proportion of immunosuppressed fish released from each raceway, which were calculated based upon the 10 and $35 \%$ in-hatchery mortality rates (see Table 2). These results were tested against the null hypothesis in the manner described above.

\section{RESULTS}

\section{Spawner infection levels}

Fifteen of the 30 spawners in the high-BKD segregate had detectable levels of antigen in their ovarian fluid (Pascho et al. 1991). The calculated ovarian fluid concentrations range from 77 to over $13000 \mathrm{ng} \mathrm{ml}^{-1}$ ovarian fluid. These and the estimated per-egg antigen concentrations are shown in Table 1.

\section{Immunosuppression induction calculations}

Method 1

Eleven of the 30 spawners were calculated to have over $250 \mathrm{ng} \mathrm{ml}^{-1}$ of soluble antigen in their ovarian fluid and were assumed to have produced all immunosuppressed progeny, due to the expected antigen concentration in their eggs. The 3 high-BKD raceways (B19 to 21) had the progeny of 2, 6 and 3 such spawners, respectively (Table 1). The minimum concentration among the 11 spawners considered to produce immunosuppressed 
Table 1. Renibacterium salmoninarum in salmon. Ovarian fluid ELISA values (from Pascho et al. 1991) and calculated antigen concentrations for the 30 high-BKD segregate female spawners. +: spawners calculated to produce immunosuppressed progeny, Method $1 ;{ }^{*}$ : no. of cases in which spawners produced immunosuppressed progeny, Method 2; nd: not detected

\begin{tabular}{|c|c|c|c|c|c|c|c|c|}
\hline \multirow{3}{*}{$\begin{array}{l}\text { Raceway \# } \\
\text { B19 }\end{array}$} & \multirow{3}{*}{$\begin{array}{c}\text { Nursery } \\
\text { tank \# } \\
33\end{array}$} & \multirow{3}{*}{$\begin{array}{c}\text { Female \# } \\
1190\end{array}$} & \multirow{3}{*}{$\begin{array}{c}\text { Ovarian fluid } \\
\text { ELISA } \\
0.043\end{array}$} & \multirow{3}{*}{$\begin{array}{l}\begin{array}{c}\text { Ovarian fluid } \\
\text { antigen } \\
\text { conc. }\left(\text { ng ml } l^{-1} \text { ) }\right.\end{array} \\
\text { nd }\end{array}$} & \multirow{3}{*}{$\begin{array}{l}\text { Ovarian fluid } \\
\text { MF-FAT } \\
0\end{array}$} & \multirow{2}{*}{$\begin{array}{c}\text { In-ovum } \\
\text { antigen } \\
\text { conc. }\left(\text { ng egg }{ }^{-1} \text { ) }\right.\end{array}$} & \multicolumn{2}{|c|}{$\begin{array}{l}\text { Immunosuppressed } \\
\text { progeny }\end{array}$} \\
\hline & & & & & & & Method 1 & Method 2 \\
\hline & & & & & & & & \\
\hline B19 & 33 & 1172 & 0.279 & 459 & 1644000 & 92 & + & $* * *$ \\
\hline B19 & 33 & 1086 & 0.048 & nd & 1664 & & & \\
\hline B19 & 33 & 1216 & 0.046 & nd & 85 & & & \\
\hline B19 & 33,34 & 798 & 0.047 & nd & 2176 & & & \\
\hline B19 & 33,34 & 998 & 0.043 & nd & 341 & & & \\
\hline B19 & 34 & 1058 & 0.047 & nd & 427 & & & \\
\hline B19 & 34 & 964 & 0.042 & nd & 7552 & & & \\
\hline B19 & 34 & 138 & 0.044 & nd & 512 & & & \\
\hline B19 & 34 & 104 & 0.709 & 13028 & 1024000000 & 2606 & + & $* * * * *$ \\
\hline B20 & 49 & 952 & 0.045 & nd & 1621 & & & \\
\hline B20 & 49 & 1052 & 0.528 & 3187 & 22613333 & 637 & + & $* * * *$ \\
\hline B20 & 49 & 106 & 0.072 & 92 & 247467 & 18 & & ${ }^{* *}$ \\
\hline B20 & 49 & 1000 & 0.707 & 12826 & 9002660000 & 2565 & + & $* * * * *$ \\
\hline B20 & 49,50 & 1002 & 0.047 & nd & 104064 & & & ${ }^{* *}$ \\
\hline B20 & 49,50 & 746 & 0.044 & nd & 4480 & & & \\
\hline B20 & 50 & 130 & 0.655 & 8559 & 704000000 & 1712 & + & $* * * * *$ \\
\hline B20 & 50 & 112 & 0.465 & 1952 & 8917333 & 390 & + & $* * *$ \\
\hline B20 & 50 & 102 & 0.696 & 11775 & 13184000000 & 2355 & + & $* * * * *$ \\
\hline B20 & 50 & 832 & 0.627 & 6884 & 230400000 & 1377 & + & $* * * * *$ \\
\hline B21 & 65 & 762 & 0.046 & nd & 3115 & & & \\
\hline B21 & 65 & 122 & 0.522 & 3841 & 47360000 & 768 & + & $* * * *$ \\
\hline B21 & 65 & 1196 & 0.050 & 77 & 72320 & 15 & & ${ }^{*}$ \\
\hline B21 & 65 & 1108 & 0.058 & 82 & 273067 & 16 & & $* *$ \\
\hline B21 & 65,66 & 834 & 0.047 & nd & 2304 & & & \\
\hline B21 & 65,66 & 1206 & 0.045 & nd & 78336 & & & $*$ \\
\hline B21 & 66 & 32 & 0.323 & 647 & 75648 & 129 & + & $*$ \\
\hline B21 & 66 & 1106 & 0.685 & 10809 & 5888000000 & 2162 & + & $* * * * *$ \\
\hline B21 & 66 & 132 & 0.047 & nd & 5077 & & & \\
\hline B21 & 66 & 42 & 0.064 & 86 & 123008 & 17 & & $* *$ \\
\hline
\end{tabular}

progeny was $459 \mathrm{ng} \mathrm{ml}^{-1}$. The other 4 female spawners testing positive via the ELISA test had calculated concentrations between 77 and $92 \mathrm{ng} \mathrm{ml}^{-1}$. Therefore, there was a factor of 5 difference between the lowest concentration considered to induce immunosuppression in progeny and the highest concentration considered to result in normal progeny, according to this method of determining immunosuppression induction.

\section{Method 2}

Based upon ovarian fluid bacterial loads, with break points of $10^{8}, 10^{7}, 10^{6}, 10^{5}$, and $10^{4}$ bacteria $\mathrm{ml}^{-1}$ respectively, a total of $6,8,10,14$ or 17 of the 30 spawners would be characterized as immunosuppression inducing. The breakdown is 1,4 , and $1 ; 1,5$ and $2 ; 2,6$, and $2 ; 2,8$ and 4 ; and 2, 8 and 7 such spawners in raceways B19 to B21, respectively (Table 1 ). The rounded averages of these 5 possibilities are 2,6, and 3, identical to the numbers in the previous calculation. Therefore, the progeny of 11 spawners were assumed to be immunosuppressed based upon both methods of calculation, and without assuming either mechanism exclusively. The other 19 spawners were assumed to produce only non-immunosuppressed progeny. The choice of these numbers is not particularly important to the results of this paper, as the other 5 possible breakdowns presented would produce similar conclusions, with the caveat that with the more conservative break points of $10^{8}$ and $10^{7}$ cells $\mathrm{ml}^{-1}$, the conclusions would be somewhat weakened, while at $10^{5}$ or $10^{4}$ cells $\mathrm{ml}^{-1}$, the conclusions would be strengthened. What is most important is that the progeny of the largest number of most highly infected female spawners were placed in Raceway B20, that Raceway B19 had the progeny of the smallest number of such spawners, and that a good number of spawners placed in the high-BKD group had relatively low levels of infection, which were unlikely to be detrimental to their offspring. 


\section{In-hatchery infection levels}

The calculated proportions of individuals that exceeded the threshold for testing positive or having medium or high infection status for both the low and high-BKD segregates at the 5 stages of testing are shown in Fig. 1. Because most samples were pooled, confidence intervals are relatively large in all but the smolt stage, where samples were not pooled. There are no significant differences between the high- and lowBKD segregates until the pre-smolt stage, for which there are slightly more individuals with medium and high infections in the high-BKD segregate.

For pre-ponding fry, the detection of individuals with medium and high infection levels only in the high-BKD segregate is not statistically significant. However, the 3 pools showing these levels of infection are from nursery tanks 49,50 and 66, each of which contained progeny of one of the 4 most highly infected female spawners. This may be indicative of the expected few percentage points of vertical infection. At the parr stage, as well, the very highest ELISA values were from the high-BKD raceways, again possibly indicating some degree of vertical infection, though by this stage this could simply be evidence of a combined effect of antigen-induced and temperature-mediated immunosuppression.

Both segregates had very high prevalence of infection (perhaps $100 \%$ ) at the parr stage, with almost identical proportions with medium or high infection levels. Reduced prevalence and levels of infection are seen at the presmolt stage, 4 mo later, likely due to higher temperatures during this period which resulted in improved immune system functioning. The first major difference between the segregates was seen at the smolt stage in which the prevalence and levels are both much higher among the high-BKD segregate.

These calculations confirm that the patterns of infection are essentially the same between the 2 segregates throughout rearing prior to the smolt stage. Infection prevalences and levels peaked in July 1989, decreased by November 1989, then increased significantly only in the high-BKD segregate by March 1990, just before release. These results are contradictory to what would be expected if vertical infection alone was the underlying cause, but are in line with the p57 antigen immunosuppression induction and low temperature immunosuppression hypotheses.
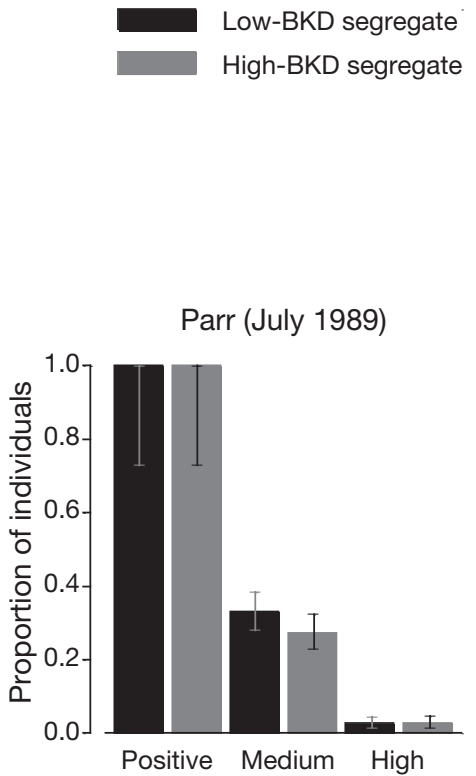

Swimup Fry (December 1988)

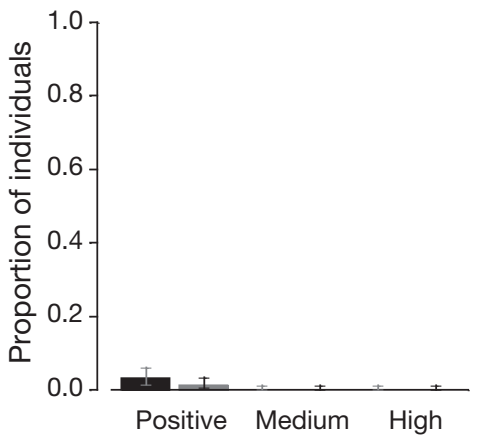

Presmolts (November 1989)

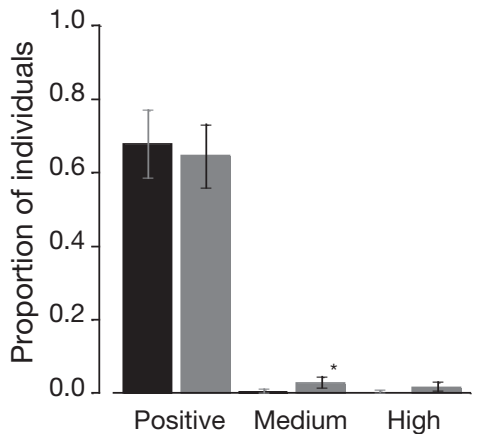

Pre-ponding Fry (April 1989)

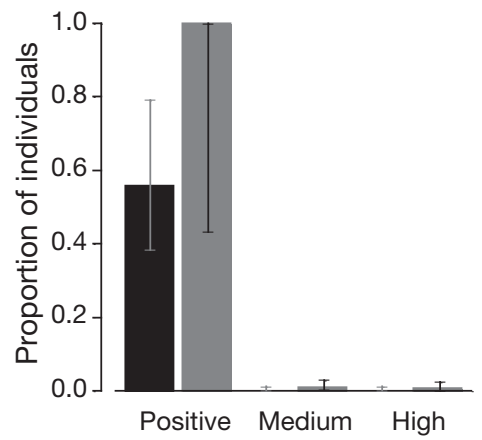

Smolts (March 1990)

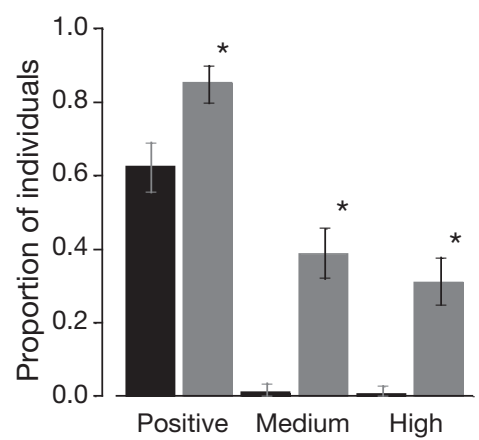

Fig. 1. Renibacterium salmoninarum in salmon. Calculated proportion of individual juvenile salmon that were positive, with medium or greater and with high infection levels, and $95 \%$ confidence intervals, at the 5 times they were tested during hatchery rearing. Significant $(\mathrm{p}=0.05)$ differences between the 2 segregates are marked *. Note that the 'medium' proportion is a subset of the positive proportion, and the 'high' proportion is a subset of the medium proportion 
Table 2. Renibacterium salmoninarum in salmon. Predicted percent immunosuppressed (IS) at hatch and release, predicted and actual hatchery survivorship, and total returns from each raceway. The average return rate $(\rho=0.0535 \%)$ among the 3 low-BKD raceways (B16-18) is used as the basis for predicting returns from all 6 raceways. Returns are modeled as arising from a Poisson distribution with mean $\rho \mathrm{N}$, where $\mathrm{N}$ is either the total number released or the number of non-immunosuppressed (non-IS) fish released from each raceway. The 1 -sided $p$-values (testing for low returns at a $p=0.05$ level) are based upon these Poisson distributions and are calculated for each raceway and for each segregate. The results for the low-BKD segregate are included largely to show possible over-dispersion. Significant results are in bold

\begin{tabular}{|c|c|c|c|c|c|c|c|c|c|c|c|}
\hline \multirow{2}{*}{$\begin{array}{l}\text { Raceway } \\
\text { or } \\
\text { segregate }\end{array}$} & \multirow{2}{*}{$\begin{array}{c}\text { IS } \\
\text { at hatch } \\
(\%)\end{array}$} & \multirow{2}{*}{$\begin{array}{c}\text { Predicted } \\
\text { hatchery } \\
\text { survival (\%) }\end{array}$} & \multirow{2}{*}{$\begin{array}{c}\text { Actual } \\
\text { hatchery } \\
\text { survival (\%) }\end{array}$} & \multirow{2}{*}{$\begin{array}{l}\text { IS at } \\
\text { release } \\
(\%)\end{array}$} & \multicolumn{2}{|c|}{ Releases } & \multicolumn{2}{|c|}{ Expected returns } & \multirow{2}{*}{$\begin{array}{l}\text { Observed } \\
\text { returns }\end{array}$} & \multicolumn{2}{|c|}{$\mathrm{p}$ value } \\
\hline & & & & & Total & Non-IS & Total & Non-IS & & Total & Non-IS \\
\hline B16 & 0 & 90.0 & 91.7 & 0 & \multicolumn{2}{|c|}{25369} & \multicolumn{2}{|c|}{13.6} & 13 & \multicolumn{2}{|c|}{0.51} \\
\hline B17 & 0 & 90.0 & 91.9 & 0 & \multicolumn{2}{|c|}{25483} & \multicolumn{2}{|c|}{13.6} & 8 & \multicolumn{2}{|c|}{0.07} \\
\hline B18 & 0 & 90.0 & $86.3^{\mathrm{a}}$ & 0 & \multicolumn{2}{|c|}{25685} & \multicolumn{2}{|c|}{13.7} & 20 & \multicolumn{2}{|c|}{0.96} \\
\hline Low & 0 & 90.0 & 90.0 & 0 & \multicolumn{2}{|c|}{76557} & \multicolumn{2}{|c|}{40.9} & 41 & \multicolumn{2}{|c|}{0.54} \\
\hline B19 & 20 & 85.0 & 84.7 & 15.3 & 22645 & 19182 & 12.1 & 10.3 & 6 & 0.04 & 0.11 \\
\hline B20 & 60 & 75.0 & 75.6 & 52.0 & 24801 & 11904 & 13.3 & 6.4 & 4 & 0.003 & 0.24 \\
\hline $\mathrm{B} 21$ & 30 & 82.5 & 82.9 & 23.6 & 24582 & 18772 & 13.2 & 10.0 & 9 & 0.16 & 0.45 \\
\hline High & 37 & 80.8 & 81.1 & 30.8 & 72028 & 49858 & 38.5 & 26.7 & 19 & 0.0004 & 0.08 \\
\hline \multicolumn{12}{|c|}{$\begin{array}{l}{ }^{a} \text { The observed survivorship in Raceway B18 includes an anomalous early mortality event unrelated to BKD. After accounting } \\
\text { for the increased mortality in the first } 2 \text { mo of hatchery rearing by assuming the same average mortality rate among the } \\
\text { remaining juveniles as in the other } 2 \text { low-BKD raceways, the predicted survivorship in Raceways B16, B17 and B18 would be } \\
91.8,91.8 \text { and } 85.8 \% \text {, much closer to the observed values and confirming the consistency in mortality rates among the } 3 \text { low- } \\
\text { BKD raceways }\end{array}$} \\
\hline
\end{tabular}

\section{In-hatchery mortality}

Actual and modeled in-hatchery mortality rates are given in Table 2. In particular, given the 2, 6 and 3 female spawners with adequate ovarian fluid antigen concentrations or bacterial loads to produce immunosuppression, the model predicts 85,75 and $82.5 \%$ survival in raceways B19, B20 and B21, respectively, quite close to the observed survival rates of $84.7,75.6$ and $82.9 \%$.

The mortality rates by month are shown in Fig. 2. There was no difference in mortality rates (except for the anomalous high rates in raceway B18 in the first 2 mo) between the low- and high-BKD raceways between November 1988 and June 1989, at which point both segregates had high rates of infection (Fig. 1). After this point, in the period in which temperatures surpassed $10^{\circ} \mathrm{C}$, mortality rates dropped to almost zero in the low-BKD raceways, while significant mortality continued in all 3 high-BKD raceways.

The drop-off in both mortality rates and infection levels after temperatures surpassed $10^{\circ} \mathrm{C}$ is in line with what is known about the effect of temperature on the functioning of cell mediated immunity and the development of the juvenile immune system at low temperatures. It is also consistent with the observed effect of temperature on BKD-related mortality as reported by Sanders et al. (1978), if one assumes a continuous increase in immune functioning as temperature increases and an interaction of immune functioning with infection level to determine survivorship.

\section{Comparison of hypotheses to explain differences in smolt to adult returns}

Two of the 3 raceways (B19 and B20) had returns low enough to reject the null hypothesis that there was no difference in quality between the high- and low-BKD segregates. The entire high-BKD segregate had significantly lower returns than the low-BKD segregate $(p<0.0005)$, convincingly rejecting the hypothesis that there was no difference in quality between the 2 segregates at release (Table 2).

After allowing for the $10 \%$ mortality of normal juveniles and the $35 \%$ mortality of immunosuppressed juveniles during hatchery rearing, what remained were 15.3, 52.0 and $23.6 \%$ immunosuppressed smolts at release from raceways B19, B20 and B21, respectively. Under the assumption that all immunosuppressed fish die, and that immunosuppression is the only substantial difference in quality between the 2 segregates, the null hypothesis of no difference between non-immunosuppressed fish in either segregate is not rejected for any of the individual raceways nor for the entire high-BKD segregate (Table 2). The exclusion of immunosuppressed fish accounts for $60 \%$ of the difference between the proportion returning from the 2 segregates. This remaining difference, though not significant, could partially be attributed to some degree of immunosuppression induction among the progeny of female spawners that tested positive for soluble antigen or had moderate levels of bacteria in their ovarian fluid but were 


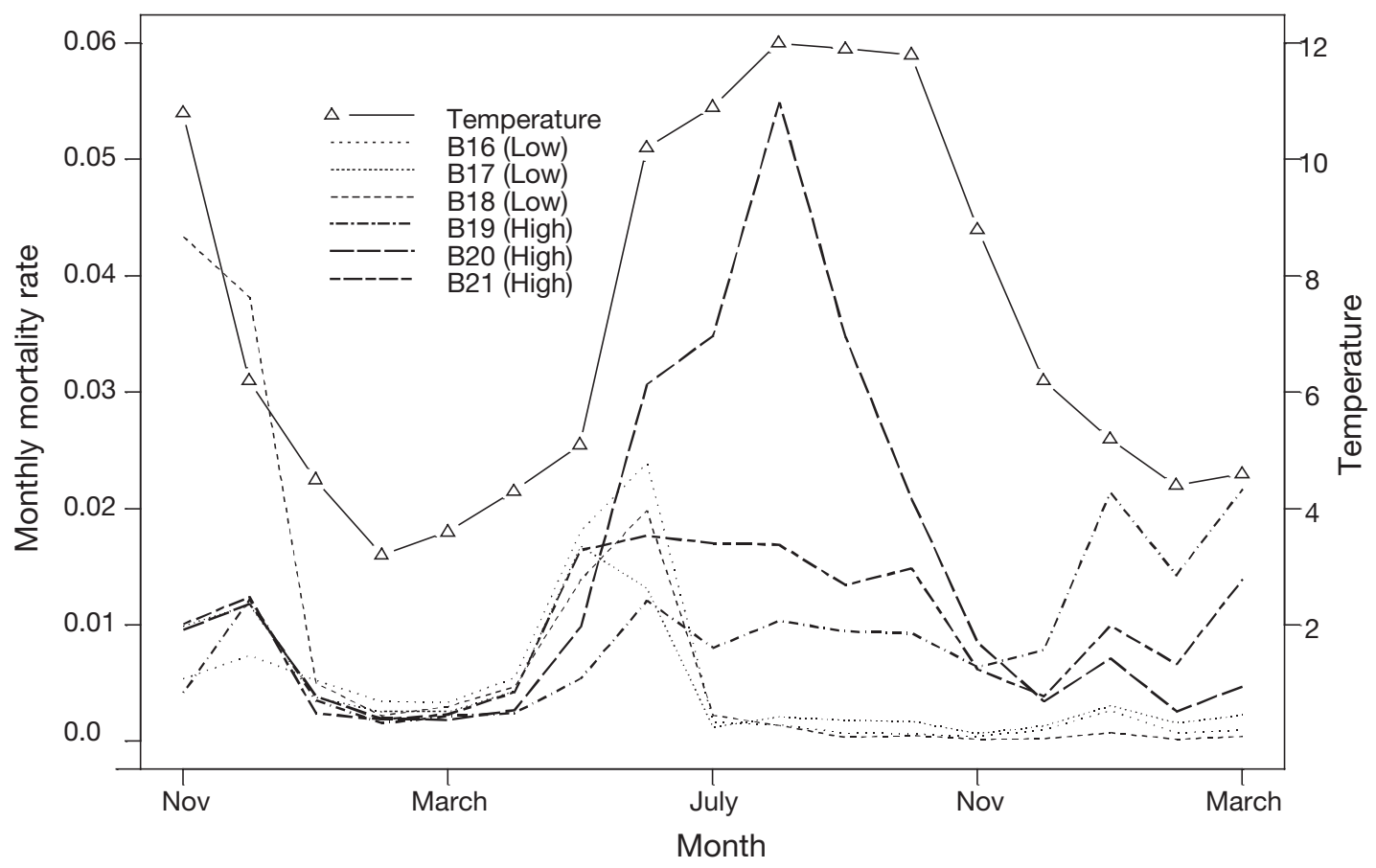

Fig. 2. Renibacterium salmoninarum in salmon. Monthly rates of mortality in each of the 6 raceways and mean monthly temperature $\left({ }^{\circ} \mathrm{C}\right)$ during hatchery rearing. The recovery of juveniles in all 3 low-BKD raceways in July 1999, just after temperatures surpass $10^{\circ} \mathrm{C}$ for the first time since hatch, is seen by the extremely low monthly mortality rates for those 3 raceways. Previous to that, mortalities were indistinguishable from the 3 high-BKD raceways. In contrast, the 3 high-BKD raceways experienced continued or increasing mortality. In particular, raceway 20, with the highest number of very highly infected female spawners, exhibits a strong peak in mortality rates from July through October 1999

below the threshold used in Method 1 for calculating the proportion of immunosuppressed progeny from each raceway.

\section{DISCUSSION}

As Pascho et al. (1991) noted, there was a higher overall mortality rate through raceway rearing as well as higher prevalence and levels of BKD at release in the high-BKD segregate. However, the data do not suggest that vertical transmission alone was the cause of these differences. No significant differences in infection prevalences or levels between the 2 segregates occurred until the pre-smolt stage, at 12 mo after hatch. In particular, the lack of distinction between the prevalence and severity of infection through the parr stage, coupled with significant levels of infection in all 6 raceways at that time, indicates little or no effect of vertical transmission. While the $1 \%$ observed highly infected fry in the high-BKD group at 5 mo after hatch may indeed be due to vertical transmission, this is too small a rate to account for later differences in survival and infection levels between the 2 groups. Nor does this small percentage of fish with high infection levels appear to result in significant increased horizontal transmission between juveniles. Most of the infection must initially be due to an external source, given the high levels observed in all raceways at the parr stage. It appears that a difference in the immune functioning of at least a portion of the high-BKD group causes subsequent increased prevalence and levels of the disease, as well as increased mortality during and after hatchery residence.

The finding by Brown et al. (1996) that the inclusion of $100 \mathrm{ng}$ of the antigen p57 in the egg induced immunosuppression in fry, is sufficient to explain the observed differences in response to the disease between the 2 segregates. There remains, then, the conundrum of the lack of differences in the first $8 \mathrm{mo}$ post hatch. This is best explained by the cold temperatures (below $10^{\circ} \mathrm{C}$ ) experienced by the fry during the first 7 to 8 mo after hatch (Fig. 2). These low temperatures impair the development and functioning of the cell mediated immune system, possibly including helper T-cells (Bly \& Clem 1992, Hardie et al. 1994), preventing an effective immune response by individuals in both segregates. Higher subsequent temperatures allow individuals in the low-BKD segregate to fight off the disease, whereas some members of the 
high-BKD group are still impaired due to in-ovum antigen induced immunosuppression. Higher temperatures result in more rapid bacterial replication in this experiment, as the temperatures in the hatchery never reach the optimum for growth of this bacterium. The difference in infection severity observed between the 2 segregates at the smolt stage is likely due to immunosuppression coupled with one or more of the following factors: low winter temperatures, increased levels of cortisol associated with smoltification, and the handling stress and risk of transmission from coded wire tagging procedures (Elliott \& Pascho 2001) which occurred 4 mo prior to release. While the nonimmunosuppressed fish experienced the latter 3 factors as well, it appears some combination of the factors, including immunosuppression, produced the observed effect.

The scenario described by the model developed in this paper is as follows: At hatch, 20,60 and 30\% of the salmon destined for raceways B19, B20 and B21 respectively are immunosuppressed as in Table 2 (though the calculations work as well for other scenarios suggested above). No immunosuppression occurs in the 3 low-BKD segregate raceways. Initial infection is assumed to occur through the introduction of bacteria in the untreated river water used in the hatchery and through a very minimal occurrence of vertical transmission among the high-BKD segregate, affecting a few percent of that population. Again, vertical transmission may play a larger role as the source of the antigen within the egg, though the evidence for such widespread vertical transmission is weak. Continued environmental and horizontal infection sources result in nearly $100 \%$ infection prevalence in both segregates by the parr stage (Fig. 1). Increasing temperatures result in more rapid replication of the bacteria, but also in increased immune system functioning, especially among non-immunosuppressed fish. Mortality among the non-immunosuppressed fish falls to almost zero after this point, while mortality continues among the immunosuppressed fish. Continued high infection levels and BKD-related mortality result in greater bacterial loads in the high-BKD raceways and likely higher infection prevalences among nonimmunosuppressed fish in those raceways. Individuals of both segregates experience convalescence due to higher temperatures, but immunosuppressed fish with high levels of infection are still likely to die, and those with moderate levels of infection are less likely to recover than non-immunosuppressed fish. Finally, some combination of the low temperatures over winter, the increases in cortisol related to smoltification, and the stress and risk of transmission from coded-wiretagging procedures, result in increased infection levels in the high-BKD segregate at release. In fact, $31 \%$ of the high-BKD segregate tested at release had high infection levels, almost exactly the percentage calculated to be immunosuppressed at release. Only $0.5 \%$ of the low-BKD segregate had high infection levels at this stage.

During hatchery rearing, juveniles are modeled as experiencing approximately 35\% mortality for immunosuppressed progeny and 10\% mortality among non-immunosuppressed progeny. At release, the highBKD segregate is calculated to be composed of $31 \%$ immunosuppressed fish. The effect of such a high proportion of immunosuppression is seen in the relative recovery rate (high-BKD segregate recapture/lowBKD segregate recapture) for transportation at 3 dams downstream of release, as recorded via passive integrated transponder (PIT) tags in about 6000 of the released smolts (Pascho et al. 1993). These were 93\% at Lower Granite Dam and $73 \%$ at both Little Goose Dam and McNary Dams. This indicates no more than $73 \%$ relative survivorship for in-river migrants. This is similar to the expected $69 \%$ relative survivorship assuming all immunosuppressed fish die during inriver migration.

The effect is also seen in a 14 wk saltwater challenge experiment imposed upon 25 smolts retained from each raceway (Elliott et al. 1995). In this experiment, $42 / 75$ of the high-BKD segregate survived compared to $66 / 75$ of the low-BKD segregate, giving a relative survival of $42 / 66$ (64\%). This, again, is very close to the expected relative survivorship (69\%) due to the proportion of immunosuppressed fish in the high-BKD segregate at release.

Total returns were $41 / 76557(0.0536 \%)$ for the lowBKD segregate and 19/72028 (0.0264\%) for the highBKD segregate, for a relative return rate of $49 \%$. This is a little below the expected $69 \%$, but the difference is not significant given the very small number of returns, even under the strict assumption that the mean return rate observed in the low-BKD segregate is the expected rate for all non-immunosuppressed fish $(\mathrm{p}=$ 0.08) (Table 2).

The differences in hatchery survivorship and smoltto-adult return rate observed among the 3 high-BKD raceways can be directly related to the level of infection in the ovarian fluid (whether measured by ELISA or MF-FAT) of the 10 female spawners whose progeny were reared in each raceway (Table 2). Pascho et al. (1991) attributed the pattern of infection and mortality to some unknown mechanism, while considering immunosuppression induction as one possible explanation. They considered segregation to be central to the results and effective at reducing overall mortality. Alternatively, as has been quantitatively demonstrated in this paper, brood stock segregation might serve only to separate progeny with different probabilities of sur- 
vivorship, without necessarily changing the overall survivorship rate of the population. It is possible that the mortality in non-immunosuppressed fish is independent of their exposure to immunosuppressed and/or vertically infected fish. To test if immunosuppression is indeed behind the differences between returns, a similar experiment could be undertaken with genetic tests performed on both spawners and returning salmon; this would provide definitive parentage information for returning salmon. A less time-consuming experiment would involve directly testing for immunosuppression induction in progeny of highly infected spawners.

This analysis has a number of management implications for the control of BKD in hatcheries. It is not clear that segregation makes any difference in the inhatchery mortality rate or the return rate, when the entire hatchery population is considered. Thus, culling the eggs of very highly infected female salmon is likely a more economical and effective action, unless the number of spawners is critically limited. Water supplies may be the major source of infection with Renibacterium salmoninarum, and therefore water sterilization should be undertaken if possible. Low temperatures exacerbate the infection, while higher temperatures may aid in recovery; thus, artificially increasing rearing temperatures for a period may be indicated where summer water temperatures do not exceed $10^{\circ} \mathrm{C}$ for an extended period.

Acknowledgements. This work was partially supported by the Bonneville Power Administration under contract 00005396 (Project 89-108) through Columbia Basin Research of the School of Aquatic and Fisheries Sciences at the University of Washington. The author would like to thank J. Anderson for his guidance, D. Elliott and R. Pascho for access to their data, M. Liermann, W. Dickhoff, and 2 anonymous reviewers for their insights, and especially L. Rhodes for several discussions which substantially improved the presentation of this material.

\section{LITERATURE CITED}

Austin B, Rayment JN (1985) Epizootiology of Renibacterium salmoninarum, the causal agent of bacterial kidney disease in salmonid fish. J Fish Dis 8:505-509

Balfry SK, Albright LJ, Evelyn TPT (1996) Horizontal transfer of Renibacterium salmoninarum among farmed salmonids via the fecal-oral route. Dis Aquat Org 25:63-69

Banner CR, Rohovec JS, Fryer JL (1983) Renibacterium salmoninarum as a cause of mortality among chinook salmon in salt water. J World Maricul Soc 14:236-239

Banner CR, Fryer JL, Rohovec JS (1986) Occurrence of salmonid fish infectedwith Renibacterium salmoninarum in the Pacific Ocean. J Fish Dis 9:273-275

Bly JE, Clem LW (1992) Temperature and teleost immune functions. Fish Shellfish Immunol 2:159-171

Brown LL, Iwama GK, Evelyn TPT, Nelson WS, Levine RP (1994) Use of the polymerase chain reaction (PCR) to detect DNA from Renibacterium salmoninarum within individual salmon eggs. Dis Aquat Org 18:165-171

Brown LL, Iwama GK, Evelyn TPT (1996) The effect of early exposure of coho salmon (Oncorhynchus kisutch) eggs to the p57 protein of Renibacterium salmoninarum on the development of immunity to the pathogen. Fish Shellfish Immunol 6:149-165

Bruno DW (1986) Histopathology of bacterial kidney disease in laboratory infected rainbow trout, Salmo gairdneri Richardson, and Atlantic salmon, Salmo salar L., with reference to naturally infected fish. J Fish Dis 9:523-527

Bullock GL, Wolf K (1986) Infectious diseases of cultured fishes: current perspectives. Fish disease leaflet no. 5, U S Fish and Wildlife Service

Elliott DG, Barila TY (1987) Membrane filtration-fluorescent antibody staining procedure for detecting and quantifying Renibacterium salmoninarum in coelomic fluid of chinook salmon (Oncorhynchus tshawytscha). Can J Fish Aquat Sci 44:206-210

Elliott DG, Pascho RJ (1995) Juvenile fish transportation: Impact of bacterial kidney disease on survival of spring/ summer chinook salmon stocks. Annu Rep 1993, US Army Corps of Engineers

Elliott DG, Pascho RJ (2001) Evidence that coded-wiretagging procedures can enhance transmission of Renibacterium salmoninarum in chinook salmon. J Aquat Anim Health 13:181-193

Elliott DG, Pascho RJ, Bullock GL (1989) Developments in the control of bacterial kidney disease of salmonid fishes. Dis Aquat Org 6:201-215

Elliott DG, Pascho RJ, Palmisano AN (1995) Brood stock segregation for the control of bacterial kidney disease can affect mortality of progeny chinook salmon (Oncorhynchus tshawytscha) in seawater. Aquaculture 132: 133-144

Elliott DG, Pascho RJ, Jackson LM, Matthews GM, Harmon JR (1997) Renibacterium salmoninarum in spring-summer chinook salmon smolts at dams on the Columbia and Snake rivers. J Aquat Anim Health 9:114-126

Evelyn TPT (1996) Infection and Disease. In: Iwama G, Nakanishi $\mathrm{T}$ (eds) The fish immune system: organism, pathogen and environment. Academic Press, San Diego, CA, p 339-366

Evelyn TPT, Ketcheson JE, Prosperi-Porta L (1984) Further evidence for the presence of the kidney disease bacterium (Renibacterium salmoninarum) and the failure of iodine, in the form of povidone-iodine, to reduce the intra-ovum infection rate in water-hardened eggs. J Fish Dis 7: 173-182

Evelyn TPT, Prosperi-Porta L, Ketcheson JE (1986) Experimental intra-ovum infection of salmonid eggs with Renibacterium salmoninarum and vertical transmission of the pathogen with such eggs despite their treatment with erythromycin. Dis Aquat Org 1:197-202

Evenden AJ, Grayson TH, Gilpin ML, Munn CB (1993) Renibacterium salmoninarum and bacterial kidney diseasethe unfinished jigsaw. Annu Rev Fish Dis 3:87-104

Griffiths SG, Lynch WH (1991) Instability of the major soluble antigen produced by Renibacterium salmoninarum. J Fish Dis 14:55-66

Groberg WJ, McCoy RH, Pilcher KS, Fryer JL (1978) Relation of water temperature to infection of coho salmon (Oncorhynchus kisutch), chinook salmon (O. tshawytscha), and steelhead trout (Salmo gairdneri) with Aeromonas salmonicida and A. hydrophila. J Fish Res Board Can 35: $1-7$

Guđmundsdóttir S, Helgason S, Sigurjónsdóttir H, Mathías- 
dóttir S, Jónsdóttir H, Laxdal B, Benediktsdóttir E (2000) Measures applied to control Renibacterium salmoninarum infection in Atlantic salmon: a retrospective study of two sea ranches in Iceland. Aquaculture 186:193-203

Gutenberger SK, Duimstra JR, Rohovec JS, Fryer JL (1997) Intracellular survival of Renibacterium salmoninarum in trout mononuclear phagocytes. Dis Aquat Org 28:93-106

Hamel OS, Anderson JJ (2002) Relationship between antigen concentration and bacterial load in Pacific salmon with bacterial kidney disease. Dis Aquat Org 51:85-92

Hardie LJ, Fletcher TC, Secombes CJ (1994) Effect of temperature on macrophage activation and the production of macrophage activating factor by rainbow trout, Oncorhynchus mykiss, leucocytes. Dev Comp Immunol 18: $57-66$

Hardie LJ, Ellis AE, Secombes CJ (1996) In vitro activation of rainbow trout macrophages stimulates inhibition of Renibacterium salmoninarum growth concomitant with augmented generation of respiratory burst products. Dis Aquat Org 25:175-183

Holt RA, Sanders JE, Zinn JL, Fryer JL (1975) Relation of water temperature to Flexibacter columnaris infection in steelhead trout (Salmo gairdneri), coho (Oncorhynchus kisutch), and chinook (O. tshawytscha) salmon. J Fish Res Board Can 32:1553-1559

Jansson E, Hongslo T, Johannisson A, Pilstr?m L, Timmusk S, Norrgen L (2003) Bacterial kidney disease as a model for studies of cell mediated immunity in rainbow trout (Oncorhynchus mykiss). Fish Shellfish Immunol 14: 347-362

Kaattari SL, Piganelli JD (1997) Immunization with bacterial antigens: bacterial kidney disease. In: Gudding R, Lillehaug A, Midtlyng PJ, Brown F (eds) Fish vaccinology. Karger, Basel, p 145-152

Lee EGH, Evelyn TPT (1989) Effect of Renibacterium salmoninarum levels in the ovarian fluid of spawning chinook salmon on the prevalence of the pathogen in their eggs and progeny. Dis Aquat Org 7:179-184

Manning MJ, Nakanishi T (1996) The specific immune system: cellular defenses. In: Iwama G, Nakanishi T (eds) The fish immune system: organism, pathogen and environment. Academic Press, San Diego, CA, p 160-205

Maule AG, Rondorf DW, Beeman J, Haner P (1996) Incidence of Renibacterium salmoninarum infections in juvenile hatchery spring chinook salmon in the Columbia and Snake Rivers. J Aquat Anim Health 8:37-46

Mesa MG, Maule AG, Poe TP, Schreck CB (1999) Influence of bacterial kidney disease on smoltification in salmonids: is

Editorial responsibility: David Bruno,

Aberdeen, UK it a case of double jeopardy? Aquaculture 174:25-41

Mitchum DL, Sherman LE (1981) Transmission of bacterial kidney disease from wild to stocked hatchery trout. Can J Fish Aquat Sci 36:547-551

Pascho RJ, Elliott DG, Streufert JM (1991) Brood stock segregation of spring chinook salmon Oncorhynchus tshawytscha by use of the enzyme linked immunosorbent assay (ELISA) and fluorescent antibody technique (FAT) affects the prevalence and levels of Renibacterium salmoninarum infection in progeny. Dis Aquat Org 12:25-40

Pascho RJ, Elliott DG, Achord S (1993) Monitoring of the inriver migration of smolts from two groups of spring chinook salmon, Oncorhynchus tshawytscha (Walbaum), with different profiles of Renibacterium salmoninarum infection. Aquacult Fish Manag 24:163-169

Raymond HL (1988) Effects of hydroelectric development and fisheries enhancement on spring and summer chinook salmon and steelhead in the Columbia River basin. N Am J Fish Manag 8:1-24

Sami S, Fischer-Scherl T, Hoffman RW, Pfeil-Putzien C (1992) Immune complex-mediated glomerulonephritis associated with bacterial kidney disease in rainbow trout (Oncorhynchus mykiss). Vet Pathol 29:169-174

Sanders JE, Pilcher KS, Fryer JL (1978) Relation of water temperature to bacterial kidney disease in coho salmon (Oncorhynchus kisutch), sockeye salmon (O. nerka), and steelhead trout (Salmo gairdneri). J Fish Res Board Can 35:8-11

Siegel DC, Congleton JL (1997) Bactericidal activity of juvenile chinook salmon macrophages against Aeromonas salmonicida after exposure to live or heat-killed Renibacterium salmoninarum or to soluble proteins produced by R. salmoninarum. J Aquat Anim Health 9:180-189

Turaga PSD, Weins GD, Kaattari SL (1987) Analysis of Renibacterium salmoninarum antigen production. Fish Pathol 22:209-214

VanderKooi SP, Maule AG (1999) Prevalence of Renibacterium salmoninarum in juvenile spring chinook salmon at Columbia and Snake river hatcheries, 1993-1996. J Aquat Anim Health 11:162-169

Weins GD, Kaattari SL (1999) Bacterial kidney disease (Renibacterium salmoninarum). In: Woo PTK, Bruno DW (eds) Fish Diseases and Disorders, Vol 3. Viral, bacterial and fungal infections. CAB International, New York, p 269-301

Weins GD, Chein MS, Winton JR, Kaattari SL (1999) Antigenic and functional characterization of p57 produced by Renibacterium salmoninarum. Dis Aquat Org 37:43-52

Submitted: October 6, 2004; Accepted: January 20, 2005

Proofs received from author(s): June 10, 2005 